\title{
Languages in Contact, a Blessing or a Scourge? A Case Study of Yoruba Ethnography of Greetings
}

\author{
Anthony A. Olaoye \\ Department of Linguistics and African Languages, University of Abuja, Abuja, Nigeria
}

\begin{abstract}
The paper posits that "languages in contact", a sociolinguistic phenomenon, is both a blessing and a scourge in Nigeria. This phenomenon was analyzed from both the diachronic and synchronic perspective. The author asserts that the contact between English and Yoruba in Nigeria has positive consequences such as bilingualism, multilingualism, effective code - mixing and code- switching, borrowing, bi-and multiculturalism, and language enrichment. English language came with its culture, and this has a facilitating and pervasive influence on Nigerian education system, the entrenchment of democracy and cultural best practices. These are a real blessing. However, the negative or deleterious consequences of languages in contact are devastating. These include language interference problems arising from inter-lingual phenomenon; the issue of linguistic suicide and murder, or what is called language and cultural endangerment and extinction. The ethnography of communication, especially of greeting, among the Yoruba, is fast losing its vitality, finesse and value as a result of the negative influence of English on Yoruba language and culture. The author suggests that effective language planning; both corpus and status, with a serious commitment to language documentation may be the panacea to language and cultural endangerment occasioned by languages in contact.
\end{abstract}

Index Terms - ethnography, inter-lingual, accommodation, linguistic suicide, documentation, endangerment, theosophy, ideational

\section{INTRODUCTION}

Different nations of the world have different experiences regarding the story of languages in contact. In Nigeria, it is a chequered history; traumatic socio- psychologically, politically and economically,though it is a natural sociolinguistic development which societies must contend with.Nigeria is a multilingual nation where English language has acquired the status of a second language. English languagewas implanted in Nigeria through some crucial aspects of European contact. These aspects, according to Ogunsiji (1994), which had a serious impact, include missionary activities and colonial rule. The Nigerian languages thus had contact with the English language through colonization.The consequence of this contact on the ethnography of Yoruba greetings is the main thrust of this paper.

\section{A. Language Contact Situation}

Writing on languages in contact, Comrie (2009) asserts that while much change takes place in a given language without outside interference, many changes can result from contact with other languages. When two or more languages come in contact, some socio- linguistic phenomena take place, among which are bilingualism, multilingualism, codeswitching, code- mixing, calquing, borrowing, language interference and, perhaps, creolisation and pidginisation (Olaoye, 2007). Some Nigerian languages also had contact with Arabic and French. English, as Nigeria's Lingua Franca, is a British colonial legacy which eventually became a major player in Nigerian education, politics, administration, economy and legislation. English today can be regarded as the lamp with which the Nigerian youth travel through the education tunnel. It is now being referred to as one of the major Nigerian languages (Ogundare, 2004). It is a compromise language of communication in Nigeria's multi- lingual and multi- cultural setting. The reason being that the orchestrated political resistance to the choice of an indigenous language, as a national official language (NOL), has foreclosed choosing any of the three major Nigerian languages (Hausa, Igbo and Yoruba) as a Lingua Franca. English is thus seen as the socio- linguistic and symbolic embodiment of political power and authority (Adekunle, 1974).

English is a vehicle of globalization through which came information and communication technology (ICT), which has a pervasive influence on education delivery. Through English, western democracy has become a popular and regular news menu on the nation's political agenda. Through ICT many exoglossic languages have had close contact with some Nigerian languages. The influence of these foreign languages has been overwhelming, contributing to the growth and development of the Nigerian ethnolects. Through language borrowing, vocabulary expansion is made possible by lexical modernization. Yoruba language in particular has become superbly enriched. This enrichment takes place in almost all aspects of Yoruba language.The three major Nigerian languages, Hausa, Igbo and Yoruba borrowed from English. Some of the characteristics of those borrowed words are that they are integrated into the borrowing Nigerian languages, and that consonant clusters in these words are broken with epenthetic vowels. This is an incidence of linguistic symbiosis. According to Brann (2008) the in road so exoglossic languages have brought a shift from monolingualism to multilingualism, and has thus created a class of polyglots in urban cities from the monoglots of the rural areas. 


\section{B. Negative Consequences}

The history of languages in contact, the world over, is a chequered one, the above delineated salutary consequencesnotwithstanding. The English-ization of the world, particularly the pervasive influence of English on Nigerian languages and Nigeria's polity, hasa deleterious consequence. English language inNigeria behaves like an overbearing monster, bestriding the nation, with its octopus legs, like a colossus. According to Lawal (2006), English is the most adventurous and adulterous of all the languages of the world today. It behaves, in its brazen and penetrating force, as a rapist, raping some Nigerian languages to death. French, another malevolent aggressor, is not even spared. Homogenization and hegemonization, Lawal (2006) laments, are the goals of English language expansionism.

Linguistic hegemony is manifested in three ways: (a) linguistic genocide known as linguicidal trait. In this situation, English is monopolistic, totalitarian and destructive.It decimates or kills the Nigerian languages; (b) Linguistic imperialism, a situation where English becomes a dominant language linguistically, socio-politically and economically; and (c) linguistic opportunism, a situation where English dominates other languages that can not compete with it.Linguistic genocide is of two types in Nigeria.We have suicide and murder instances. In the linguistic suicide case it is the contact between English and Nigerian languages that encouraged Nigerians to develop long throat for English for prestige purpose, and for the socio- political and economic benefits derivable from the learning of English.Speakers of the Nigerian minority languages thus plunge themselves headlong into English, leaving their own languages to die due to lack of use, neglect and misuse. This is suicidal. The murder instances are encouraged by government's retrograde language education policy. Emenanjo (2004) points out that Nigeria has no de jure national policy which can be found in one source, but that a de facto national language policy exists.Nigerian language education policy encourages the cultivation and propagation of English at the expense of the Nigerian languages.Federal government has created stiff and tough competition between English and the local languages, and has also introduced other foreign languages such as Arabic, French,Portugueseand Chinese into the Nigerian school curriculum. The Nigerian constitution also promotes the growth of English when it recommends that: 'the business of the National assembly shall be conducted in English and in Hausa, Igbo and Yoruba when adequate arrangements have been made therefore', (1999, section 51).

The same constitution recommends that, at the state level: 'the business of the House of Assembly shall be conducted in English, but the House may, in addition to English, conduct the business in one or more languages spoken in the state...' (Section 9).This is how, according to crystal (1987), in Elugbe (2008), languages can be actively promoted, passively tolerated, deliberately ignored, positively discouraged, and even banned or killed. The type of linguistic diversity we have in Nigeria is described by Elugbe (2008) as a linguistic mosaic which creates conflict between languages, and which leads to endangerment and death.Language endangerment is a serious threat arising from the negative impact of languages in contact. According to Bamgbose (2008), language endangerment is a continuum, at one end of which there are dying languages and at the other end of which there are deprived languages. Bamgbose (2008) laments that Nigerian Languages are facing threat of extinction occasioned by the Federal Government's retrograde step, particularly the scrapping of the only semi-autonomous institute devoted to its languages. This is murderous, as this movement in the wrong direction is having a toll on Nigerian Languages. English, the malevolent contact visitor is thus being more vigorously empowered to prey on Nigerian Local Languages, its hapless hosts. This trend has to be reversed, because a dead language can be equated with a dead civilization with the whole spectrum of cultures, technological imperatives, and intangible values that only a language can give life. The death of some Nigerian languages is a danger signal. The eventual creolization of Yoruba and other Nigerian languages is imminent if care is not taken.

A language isn't just a body of vocabulary or a set of grammatical rules.It is a flash of the human spirit, a vehicle through which the soul of a particular culture comes into the material world. When we lose a language we lose a vital part of the human spirit. Supporting this assertion, Maidugu (2006) adds that our indigenous languages are treasures of our culture and self-identity, but these indigenous languages are disappearing. He laments about the disappearing indigenous texts in Nigerian libraries caused by Nigerian authors who are embracing the highly patronized English language texts. Language interference is also one of the negative consequences. Many Nigerians are neither proficient in English nor good in their Mother Tongues. Inter-lingual problems are responsible for this double tragedy. The over cultivation and promotion of English at the expense of the Nigerian languages may be the cause of this scourge.

It is equally worrisome that some Nigerian languages- Hausa, Igbo and Yoruba- also constitute another source of endangerment. Hausa language is threatening the survival of Kanuri and other northern Nigerian minority languages. Haruna (2006) describes this situation as a serious desertification and deforestation in the linguistic landscape. According to him, the Hausa -ization of Northern Nigeria is responsible for the murder threat on Tula, in Kaltungo LGA of Gombe State (Emenanjo and Bleambo, 1999). Yoruba language too behaves like the rapacious English that is decimating Nigerian Languages. Language death in the Middle Belt of Nigeria is a case of murder or suicide (Yusuf 2006). In suicide case, languages with some degree of similarities gradually eat each other up. This seems to be the case of the Ajowa - Akoko in relation to Yoruba. It is language murder when the National policy on education forces some speech communities to adopt a major language. Ogorii relation to Yoruba falls in this murder category case. The survival of many South- South and Mid-West minority languages is also being threatened by Igbo. This is a case of dog eats other dogs. This is unpalatable.

Languages in contact also affect people's cultures in contact both positively and negatively. The culture of the speakers of English was also imported to Nigeria. This affected the host cultures of the people with which English 
language had contact. English language and culture have a pervasive influence on Nigerian cultures in the area of food, dress, occupation, health, customs and traditions, values and belief system including education and technology. In many aspects of these cultural practices, the English-Yoruba contact has salutary effects on Yoruba culture. And in some respects the contact has devastating effects. One of these areas is the Yoruba ethnography of greetings.Languages in contact also bring about cultural endangerment. Olaoye (2008) observed that the much-cherished, rich, age-long Yoruba culture of greetings is fast being eroded by cultural and linguistic globalization.

\section{Ethnography of Yoruba Greetings}

The ethnography of communication, particularly greetings among the Yoruba is an interesting and intriguing sociolinguistic phenomenon. Greetings are conventional expressions used for welcoming people, or for expressing pleasure when meeting people.Greetings refer to salutations, kind well wishes, congratulatory remarks and compliments in general. It involves exchange of pleasantries between two of more people. The phrase phatic communion is used to refer to this social human desire to signal friendship, or at least to show lack of enmity. Greetings are social lubricants used for maintaining a comfortable relationship between and among people. In greetings, paralanguage is involved. Greetings among the Yoruba are accompanied by gestures such as kneeling, genuflecting, prostrating, bowing down and sometimes handshakes. A breach of this language and cultural behaviour is regarded as an act of rudeness, insolence or indiscipline, and it is often followed with a heavy sanction. Greetings follow Grice's (1975) co-operative principles, as the Yoruba culture of greetings entails a lot of co-operative interactions. Greetings also follow Leech's (1983) politeness principle which states the necessity for tact, generosity, approbation and modesty.

\section{Arabic and Yoruba in Nigeria}

Diachronic studies of Arabic language revealthat the contact with Yoruba came through Islam. As a Semitic language, Arabic has no recognizable genetic connection with Yoruba, except that the two belong to the Indo- European languagefamily. Examining the historical factors leading to the heavy linguistic borrowings and influences of Arabic on some languages, Abubakre (2002) observed that Yoruba is one of those languages which manifest appreciable linguistic convergence with Arabic. Similarities in cultural traits which explain the genetic affinity of Yoruba with Arabic have also been attested. A lot of narratives in the Yoruba Folklore lend credence to this assertion.Contacts between Arabic and Yoruba were also promoted through education.Universities, Institutes and academic institutions contributed immensely in the Arabic- Yoruba multilingualism. Arabic loanwords are transmitted through Hausa, though not all Arabic loanwords came via Hausa. Nupe, the immediate linguistic neighbour of Yoruba and Kanuri, could be said to be the linguistic conveyor belt. According to Abubakre (2002),Mande and Songhai are plausible vectors through which Arabic got transmitted to Yoruba. Some of the Arabic words loaned to Yoruba are:

\begin{tabular}{|l|l|l|}
\multicolumn{2}{c}{ ARABIC LOANED WORDS } \\
\hline ARABIC & YORUBA & ENGLISH MEANING \\
\hline Ad-du'a & Adua/adura & Prayer \\
\hline Al- barakah & Alubarika & Blessing \\
\hline Al-amr & Alamori & Matter \\
\hline Ar-rad & Ara & thunder \\
\hline Al-a: fiyah & Ala: fiya & Good health \\
\hline Al-ayb & Ala:bu & Blemish /stain \\
\hline Ar-rizq & Arisiki & Wealth \\
\hline Sabab & Sababi & Cause \\
\hline Waqt & Wakati & Time/hour \\
\hline
\end{tabular}

These Arabic loan words have to adapt to the morphological structure of Yoruba. The consonant cluster in Arabic has been broken with epenthetic vowels. This linguistic accommodation has made it possible for literary and non-literary artists to produce beautifully code- switched and code - mixed songs, lyrics, poems and proverbs."Languages in contact" is, no doubt, a welcome development, as it has contributed in no small measure, to the growth of the entertainment industries. The likes of Sunny Ade in Juju music, Haruna Ishola in Apala music, Yusuf Olatunji and S. Aka in Sakara, Sikuru Ayinde and Kolington Ayinla in Fuji, have risen to stardom in music in this language contact situation.

The transportation of foreign culture especially English and Arabic traditions to Nigeria has been noted. Yoruba traditional oral literature has been greatly influenced by Arabic literary tradition. Yoruba mythology shares certain aspects with Arabic geomancy (divination) especially Ifa. According to Abubakre (2002) many sources have noted the similarities between the Arabic form and the Yoruba Ifa, the Dahomean Fa, and the Sikidy (Sigidi in Yoruba) of the Malagasy.Arabic has also been greatly influenced by Yoruba in the diachronic and synchronic history of the two languages in contact. Instances of this reciprocal influence are in the production of Yoruba proverbs in Arabic and narration of Yoruba stories in Arabic. In these Yoruba stories, the language used is still Arabic but the setting, the plot and narrative techniques, including characterization have Yoruba origin. Who then says that Arabic and Yoruba are strange bed- fellows? The phenomenon of languages in contact is therefore a blessing.

\section{Documenting ETHNOGRAPHY OF GREETINGS}


Documentary linguistics, as a new sub-discipline within linguistics, is a relatively new coinage that dates back to only about two decades. According to Akinlabi and Connell (2007), interest and perhaps works on the state of the world linguistic heritage have increased dramatically as a form of language development or "salvage" work called documentation. Interest in work on endangered languages dates back to the mid-1990s with Connell's work in the Mambila Plateau of Nigeria and Cameroon, with the work of Gibbon, Connell and Ahoua in the Ivory cost on Ega, and with the collaborative work of Akinlabi, Connell and Ndimele on Defaka and Nkoroo in the South Eastern part of Nigeria (Akinlabi and Connell 2007).Documenting the ethnography of speaking, particularly of greetings among the speakers of three Dialects of Yoruba, namely Igbomina, Ijebu and Ijesa, involves the collection, organization, transcription and translation of primary data. The work also entails annotation of data in such a way that it is accessible to many people. What we have done in this work involves re-creating and archiving record of linguistic materials on language and culture, in order to create a data bank that could be used for teaching others about Yoruba language and the three dialects.

\section{A. Global Views on the Concept of Greetings}

Greetings are conventional expressions used for welcoming people or for expressing pleasure when meeting somebody. Greetings are so important to the Yoruba people that they refer to themselves as "Omo O Kaaro Ojiirebi" which means descendants of those who greet by saying "good morning, and how are you?” Daramola and Jeje (1967) assert that it is obligatory for parents to teach their children how to greet politely, as "Omoti a baji lowuro lodo agbalagba ti kosi mo ohunti o to lati se yoo gba eebu, yoo si gba abuku". This means that a child who wakes up early in the morning without first of all greeting the elders would be rebuked. On the other hand, a child that wakes up and first of all observes the norms associated with greetings would be highly favoured. Greetings however depend on three basic factors, viz; the time of the day, the context of greeting and the people involved, especially their age and relationship.

Paralanguage is involved in greetings. Greetings are accompanied by gestures such as kneeling down, genuflecting, prostrating, bowing down, and sometimes hand shake. A younger female person kneels down greeting an elderly person, while a younger male person prostrates and also removes his cap. A breach of this language behaviour is often regarded as an act of rudeness, insolence or indiscipline. The Yoruba people hold greetings in high esteem. This is evident from the proverbs associated with greetings, two of which are: "Ki a rinilokeere, ki a se ariya, o yoni juonje lo", which means "warm greetings satisfy more than food". The second is "Eniyanni a koti a koki, eniti a bakikotarajeni", which means greeting someone is a privilege, let him that is greeted respond promptly, after all there are people one meets without greeting them.

\section{B. Theoretical Frame Work}

The framework of analysis is our model framework called the Co-operative Politeness Hypothesis, which we found very apt in describing and analyzing the ethnography of greetings among the Yoruba. The syntactic-semantic analysis of some of the greetings was carried out, bringing out the variant forms in the three dialects and the Yoruba Standard Form. The Co-operative-Politeness Theory in this paper, our model framework, is based on Grice's (1975) co-operative principles and Leech's (1983) politeness hypothesis. Grice's pragmatic theory finds application in the ethnography of greetings of the Yoruba People. The co-operative principle has it that conversation is usually a cooperative activity. Grice believes that at any point in a conversation, a speaker should be guided by certain maxims, such as: quality speakers should say only what is true; quantity - speakers should say no more and no less than is required; relation speakers should be relevant; and manner - speakers should be perspicuous, i.e. be brief, orderly and should avoid ambiguity. Greetings follow Gricean laws or maxims, because Yoruba culture entails a lot of co-operative interactions which also involve politeness. The primary function of the co-operative maxims is that of constraining the participants in the greeting conversation to make their conversation orderly, purposeful and maximally efficient.

Leech's (1983) politeness principle also has four maxims; viz: tact, generosity, approbation and modesty. A speaker is required to be tactful rather than offensive, generous rather than dismissive or insensitive, be modest rather than boastful, and also be socially approving rather than pretentious. In greetings, as in any other communicative event, conformity to societal rules, or code of conduct, especially respect for elders and superiors, reciprocal respect for one another, condescension, accommodation and modesty are instances of the co-operative-politeness principles which interlocutors must observe. The politeness principle is motivated by the desire to maintain social equilibrium and friendly relations. These two principles are largely regulative factors which ensure that conversation does not follow a fruitless or destructive path; as principles have normative characteristics akin to moral imperatives.Greetings and politeness are universal concepts which are inseparable and indispensable. In Yoruba culture, refusal to greet others is regarded as impolite, whereas greeting people is regarded as the greatest honour that could be bestowed on those who are being greeted. Greetings and politeness are both levels of conversational interaction (Coulthard 1985, and Leech 1983).

\section{GEO-LingUistiCS OF THE AREAS}

Yoruba language is spoken mainly in Oyo, Ogun, Ondo, Osun, and Ekiti states of Western Nigeria. Speakers are also found in Kwara, Edo and Kogi States, and in the Republics of Benin (formerly Dahomey) and Togo, in Sierra Leone 
and Ghana. Some speakers are also found in the West Indies and South America, particularly in Cuba and Brazil. Yoruba language has many dialects among which are Ekiti, Igbomina, Ijebu, Ijesa, Oyo, Ondo, Owo, Ikale, Ilaje, Ikare, Yagba, Gbede, Ijumu, Ife, Ikiri, Isabe, Ijo,etc. The standard Yoruba is described by George (1981) as a blend of two closely related dialects, Oyo and Lagos.

The Ijebu dialect is spoken in Ijebu Ode Local Government Area of Ogun State. There are two main varieties, viz: the Emo variety spoken in Sagamu, Oderemo, Ipara, Isara, Iperu and Ikenne; while the Ijebu Central variety is spoken in Ijebu-Ode, Ijebu-Igbo and its environs.Ijesa dialect is spoken in about ten local government areas of Osun State. Some Ijesa speaking villages include IjebuIjesa, Enriomo, EsaOke, Odo, EtiOri, Ifewara, IpetuIjesa, IyeMogun and Ilesa.Igbomina dialect is spoken by the Igbomina who are found in both Kwara and Osun States. Igbominaland is divided into eighty districts, in three Local Government Areas, viz; Ifelodun LGA, with Share as the headquarters; Irepodun LGA with Omu-Aran as the headquarters, and Isin LGA, with Owu-Isin as the headquarters. Several types ofIgbomina dialects are spoken in different parts ofIgbominaland. The Mosan, Moye, Mohan and Ileko (EyoIgbomina) are spoken in different areas. The speakers of Mosan variety are found in Isin LGA and in Irepodun LGA of Kwara state while speakers of Moye variety are found in Ifelodun LGA. Ileko variety is spoken at the borders of Ilorin, while Mohan is spoken in Isin and Irepodun LGA.

\section{Methodology}

The data used in this paper was collected through both structured and unstructured interviews. The native speakersofStandard Yoruba, and three dialects, (Igbomina, Ijebu and Ijesa), between the ages of 60 and 100 years, were the main respondents. Yoruba students of the University of Ilorin and Abuja, and students of some Colleges of Education inIla-Orangun, Ikere-Ekiti, Oto-Ijanikin Lagos were also randomly selected and interviewed. A total of 100 respondents were sampled.Their responses were tape-recorded. Questions posed to both the aged and the students centered on certain types of Yoruba greetings, like greetings for festivals, at work, mourning, greetings to kings/chiefs, eulogy/pedigree greetings, seasonal greetings, etc. Only those forms of greetings which were adjudged by the respondents as dying were used for this paper.

\section{A. Data Analysis}

i. Types and Forms of Greetings

Greetings could be broadly sub-divided as follows:

- Daily greetings

- Periodical/seasonal greetings

- Greetings at the place of work

- Greetings to kings and Chiefs

- (Oriki) praise name greetings (i.e. eulogy or pedigree)

There are different forms of greetings which depend on the time of the day, the role relationship between the people involved, their age, sex, status, educational background, occupation and the context.

\section{B. The Sociolinguistic Structure of Greetings}

The grammatical structure of greetings among the Yoruba, (Igbomina, Ijebu, Ijesa), is determined by some sociolinguistic variables such as the time of the day, the season, status of the people being greeted and the social and psychological setting. There are two prominent structures, the first is considered to be old use, while the second structure is more contemporary.

In the standard Yoruba, the structure is:

1. a. Pronoun $+\mathrm{ku}+$ time of the day, as in:

E kuawuro or e $\mathrm{k}$ aaro = Good morning.

"E" is either plural "you" or singular "you" but called honorific plural - used for elders, kings, etc.

b. Ku awuro orkaaro = good morning, used among mates, or an elder greeting a younger person.

2. In Igbomina dialect the structure is: Pronoun + kun + the time of the day. The table below shows a comparison of standard Yoruba structure with that of Igbomina, Ijebu and Ijesa dialects, for both the old and contemporary time.

\begin{tabular}{|l|l|l|l|}
\hline Time & Standard Yoruba & Ijesa Dialect & Ijebu Dialect \\
\hline a. Morning & E ka aro babaa mi & Kaaro baba & K aaroba mi \\
\hline b. Afternoon & E kaasan baba mi & Ku osan baa mi & K aasanba mi \\
\hline c. Evening & E kuirole baba mi & In ku role baa mi & Ku role ba mi \\
\hline d. Night & E kaaaleiyami & K aaleyeemi & K aale ye mi \\
\hline
\end{tabular}

Igbomina dialect is a variant of the standard Yoruba Form:

'E kunowuro baa mior'e kun ooro baa mi'

E kunosanba mi

E kunaale baa mi or e kale baa mi

E kunowuromomo mi or e kunooro moo mi 
E kunaasanmomo mi or e kunaasan moo mi

E kunaalemomo mi or e kale moo mi

\begin{tabular}{|c|c|c|}
\hline \multicolumn{3}{|c|}{ CONTEMPORARY FORM } \\
\hline Standard Yoruba & Ijesa & Ijebu \\
\hline E Kaaro baba mi & In kaaro o baba or in pele o baa mi & Wen/E Kaarobami \\
\hline E kaasan baba mi & In kun osan o baa mi & Wen/E kaasanba mi \\
\hline E kaasaniya mi & In pele o yee mi or in kuosan oyeemi & Wen/E kaasanba mi \\
\hline E Kaale baba mi & In kale o baa mi & Wen/E Kaalebami \\
\hline E Kaaleiya mi & In Kaale o yee mi & Wen/E kale ye mi \\
\hline
\end{tabular}

The honorific or respect pronoun used by the Ijesa and Ijebu are "in" and "wen" or "e". In Ijesa dialect, "In pele" is the alternative form of "in ku".

\section{Endangered Yoruba Greetings}

English language and western civilization have made in-roads into the language and culture of the Yoruba. Many of the Yoruba greeting forms are fast disappearing from their ethnography of communication. The following greetings are gradually becoming moribund:

\section{Festival Greetings}

'E kuodun, e kuiyedun, Olorunyoo je kaseopoodunlaye'. This corresponds to happy +name of the festival, e.g. happy Christmas, happy Easter, happy Id-el-kabir, etc.may God allow us to see more of the festivals. The youths are gradually losing these structures, as they simply say "e kuodun" without adding the other deep sociolinguistic forms.

\section{E. Marriage Greetings}

'E kuinawoiyawo o, eyiniyawokonimeni'.

"You + greeting + expenses + bride + back + bride + will not+ know + mat", i.e. well-done for the expenses of the wedding, may the bride not suffer or stay long before conceiving. The youths will simply say "E kuinawo" or congratulations. Only the elders go on into detailed or more complex greetings, with well wishes or prayers.

\section{F. Childbirth Greetings}

'E kuewuomo, Olorunyoo daomonaasi', i.e. "You + greeting + risk + child + God + will + save + child + the alive". This corresponds to congratulations on the child's delivery, may God protect the child or keep the child alive.

\section{G. Greetings to Kings}

'Kabiyesi o, kade o pelori, kibatapelese', i.e. Your royal majesty, may crown stay long on your head, and may your shoes stay long on your feet. This corresponds to: long live the king! The youth just simply say: "kabiyesioo" and then prostrate, with their cap removed.

\section{H. Seasons' Greetings}

Dry season: ' 'E kuogbeleyi'

Rainy season: 'E kuoginitinyi'

Most youths do not even know the Yoruba words for dry or rainy season, or any other season for that matter.

\section{Burial Greetings}

a. 'E kuaraferaku'

You + greeting + body + missed each other

This corresponds to "sorry for missing/losing somebody" or sorry for the death of .......

b. 'Ekuileedeoloogbe, ojo a jinasira won'

You + greeting + absence + the dead + days + will be far + from + each other, i.e. sorry for the loss of the dead, may you live long.

\section{J. House Warming Greetings}

'E kuisile, ile a turao'

You + greeting + opening house + house + will + cool body, i.e. congratulations on the commissioning of the house, may the house bring you comfort.

\section{K. Occupational Greetings}

The most endangered forms of greetings are those for occupations or trades or professions. The youths hardly ever use these greeting words and phrases.

- Hunter: 'a rin pa a', i.e. may you walk and kill

- Dyeing: ' 'are du o', i.e. may you soak it dark/black

- Plaiting: 'ojugboro o', i.e. may you do it with facility

- Farming: 'a rookobodun de' - may you farm year in year out. 
- Trading: 'e kuoroaje, a tagbowo, a ta jere'.

You + greeting + matter + business + may u+sell + get money. This means well-done in your business, may you trade and prosper in it

- Palm wine taper: 'Iigba a yi o',i.e.

rope + will + strong, i.e. Your rope will be strong and will never cut

- Blacksmith:'Aro ye o',i.e.you will do smithing with success

- Ifa Priest: 'Aboruboye o, ebo a fin o', i.e.Your sacrifices will bepropitious

Marble (Ayo) players:'mokiota, mokiope', or one asks the players 'tani ope, taniota', i.e.who is losing, who is winning? Or who is the loser, and who is the winner?

- Child loser:, i.e. one whose child has died: 'e kuiroju, omi lo tuagbe kofo', which means, sorry, it's only the water that has spilled out, the calabash or gourd is not broken. This means take heart because you are still alive, it's only the child that is dead.

From these and many other greetings there are other structures found in Standard Yoruba greetings that are different from "Pronoun +ku + time of the day, season, festival", etc. pattern. "E kuise" has almost replaced all types of greetings, especially if one wants to greet somebody who is working, the type of work or job notwithstanding.

The Igbomina, Ijebu and Ijesa dialects also have similar but different structures from that found in Standard Yoruba. The morphological and syntactic structures of the greetings in Igbomina, Ijebu and Ijesa dialects are different from Standard Yoruba.

\section{Oriki Orile}

(Pedigree Greetings) More worrisome is the fact that (orikiorile) lineage praise names used in greeting are fast disappearing in the ethnography of communication of the Yoruba race. The following praise names are used to greet and inspire people:

- Abeni - female name - one who was begged before having, i.e. got through supplication to God/gods. "Abeni o", i.e. Abeni, how are you?

- Agbeke - female name: one you carry up and care for, i.e. a delicate or fragile jewel.

- Aduke - female name: one you hold tenderly to cater for.

- Abeke - female: one you beg to cater for. Every lineage has their history of chivalry, valour, defeat, sanctity, piousness, weakness, heroism, opprobrium, infamy, etc. with which they are known and greeted.

Lineage Praise names (LPN) used for greeting can be categorized into four broad based semantic types:

a. Theosophic LPN: Praise names derived from God or gods' attributes, such as:

- “O, kun, omoluwabi”, i.e. hello, God's own child. This is a form of greeting for a well-behaved child, a descendant of Noah in the Bible.

b. Testimonial LPN: names that testify to the individual's fortune, with respect to procreation, good luck, etc. such as:

- 'O kun, omoAdedibu', i.e. hello, a child from a royal family whose lineage is getting enlarged or expanded by the day.

- 'Pele o, omoIrebaayo', i.e. how are you, child whose birth has brought goodness or fortune upon joy.

- Pele o, 'Omo Otedola', i.e. hello, a child whose birth has turned conspiracy into honour and wealth.

c. Ideational LPN: Praise names that reflect cultural ideas, such as Yoruba concept of man, society, universe, goodness, death, re-incarnation, spirit world, etc. such as:

- 'O kun, omoAbioje', i.e. how are you, child born into the masquerade cult.

- 'Taiyelolu, omoiyamoye', i.e. used for greeting the first born of twins whose mother is regarded as sagacious, prudent or discreet.

d. Monumental LPN: Praise names derived from parents' personal achievements, as in physical prowess, wealth, professional excellence, courage, industry, bravery, etc. e.g:

- 'Pele o, Omo Adifala', i.e. greetings for a child whose father (an oracle priest) has been enriched through correct divination work.

- 'Pele o, omoajanakutii mi igbokijikiji', i.e. greetings for a child whose father is regarded as an elephant (a strong and brave person) whose moves shake the bush/forest very terribly.

- Others are: "Omo Akinleye" - a child whose father's heroism possesses dignity and honour; "Omo Olupefon", i.e.a child whose father is known for valorous deeds like killing "Efon" i.e. Buffalo.

Educated Yoruba youth no longer use these greeting forms, either because they do not know them, as modernizationhas taken over these forms of greeting, or they have no time for all these cultural niceties. Even among the elders, both literate and illiterate, this practice is fast dying out, and needs to be revived. A glossary of these endangered Yoruba greetings is therefore imperative.

\section{CONCLUSION}

Language contact is a sociolinguistic phenomenon which has both positive and negative consequences. In Nigeria its salutary effects are seen in people's bilingualism, multilingualism, and could also be seen as the pathway to good job opportunities. Proficiency in English has become a status symbol. Through English came globalization which also 
brought advancement in Science andTechnology. Democracy became a regular news menu on the world's political programmes, thus opening our eyes to democratic cultures and best practices. Nigerian languages got expanded and enriched in all their aspects through borrowing. Nigerian cultures also got enriched. These are, certainly, wonderful blessings.

However, the negative consequences of languages in contact seem to be more pervasive. Yoruba ethnography of greetings is facing threat of extinction, as the rich culture of greetings is being overtaken by English greetings. The Yoruba are experiencing language interference challenges, language endangerment and threat of extinction. Linguistic suicide and murder are taking their tolls on Nigerian languages. Cultural endangerment is also being faced. Neocolonialism is now the order of the day. In this respect, "languages in contact" is not a blessing but a scourge. Effective language planning and language documentation may be the panacea to language and cultural endangerment, occasioned or caused by languages in contact.

\section{REFERENCES}

[1] Abubakre, R.D. (2002).Survival of Arabic in difficult terrains. The fifty-eight inaugural lecture, University of Ilorin. 4-28.

[2] Akinlabi, A. and Connell, B. (2007).The interaction of linguistic theory, linguistic description and linguistic documentation. An unpublished paper, LAN Conference, University of Uyo, Uyo, Nigeria.

[3] Adekunle, M.A. (1974). The standard Nigerian English in sociolinguistic perspective. Journal of Nigerian English Studies Association NESA Vol. 6, No 1.

[4] Bamgbose, Ayo. (2008).Combating language endangerment and death. Is Nigeria moving in the right direction? An unpublished paper, Linguistics Association of Nigeria, University of Uyo, Uyo.

[5] Brann, C. M.B. (2008). Language policy planning and management. An unpublished paper, Linguistics Association of Nigeria. University of Maiduguri. 1-5.

[6] Comrie, B. (2009). Language. Redmond, W.A.: Microsoft Corporation.

[7] Coulhard,M.(1985).An introduction to discourse analysis, $2^{\text {nd }}$ Edition. London: Longman.

[8] Daramola and Jeje, A. (1967).Awon Asa Ati Orisa Ile Yoruba. Ibadan: Onibon Oje Press.

[9] Elugbe, Ben. (2008). Agencies set up for Nigerian Languages: the challenge of advocacy. An unpublished paper presented at the $22^{\text {nd }}$ conference of LAN. University of Maidugur.

[10] Emenanjo, E. N. and Bleambo, P.K. (ed). (1999). Language endangerment and language empowerment in Nigeria. Aba: National Institute for Nigerian Languages. 58-67.

[11] Emenanjo, N. (2004).Nigerian Languages and the Democratic Experience. Proceedings of the $9^{\text {th }}$ annual conference of ANLAT, NINLAN, Aba.

[12] Grice, P. (1975). Logic and conversation. In: P. Cole and J. L. Morgan (eds). Syntax and Semantics, Vol. 3 .New York: Academic Press.

[13] Haruna, A. (2006). Best options to safeguard endangered languages of the Trans-Saharan region. In: Proceedings of the National workshop on Best practices to safeguard endangered Nigerian Languages. Abuja: UNESCO Abuja publication.pp.50.

[14] Lawal, R. A. (2006). Linguistic globalization and sustainable democracy in Nigeria. An unpublished paper, $1^{\text {st }}$ National conference of school of languages, FCE, Kontagora, Niger State, Nigeria.

[15] Leech, G.N. (1983). Principles of Pragmatics. London: Longman Group Ltd.

[16] Maidugu, M.M. (2006). Awelcome address. Proceedings of the National workshop on Best practices to safeguard endangered Nigerian languages. UNESCO Publication: Abuja.

[17] Ogundare, M.A. (2004). The role of language teaching in national development. Language and literature in education for a better society, COE Ankpa, Nigeria.

[18] Ogunsiji, Y. (1994). The implantation and use of English in a multilingual and multicultural setting: The Nigerian example. Journal of languages and literature (JOLL), Vol. 1 No. 1, Dec. p.127.

[19] Olaoye, A. A. (2007). Introduction to sociolinguistics. Abuja: Ogunleye Israel Publishing and Printing Company.

[20] Olaoye, A.A. (2008). A sociolinguistic documentation of endangered ethnography of greetings in Yoruba language. An unpublished paper presented at the West African Linguistic Congress Conference, University of Education, Winneba, Ghana.

[21] Yusuf, O. (2006). Disappearing languages of the Middle Belt: Steps to safeguard. Proceedings of the National workshop on best practices to safeguard endangered Nigerian Languages .Abuja: UNESCO Abuja publication. 67-81.

[22] Solanke, J. (2006). What was folklore got to do with it? Endangered languages and the electronic age. Proceedings of the National workshop on best practices to safeguard endangered Nigerian Languages. Abuja: UNESCO Abuja publication. 3848.s.

Anthony A. Olaoye was born at Okerimi-Oro, in Irepudun Local Government Area of Kwara State, Nigeria on the $4^{\text {th }}$ April, 1949. The author has B.A. (Ed) English/Education, Ahmadu Bello University, Zaria, Nigeria, 1978; M.Ed Curriculum and Instruction, Bayero University, Kano, Nigeria, 1982; M.A. English Language, Bayero University, Kano, Nigeria, 1986; Ph.D, English Language (Sociolinguistics) Ahmadu Bello University, Zaria, Nigeria, 1992.

The author's major field is Applied Linguistics. He has taught English Language and Methodology in a College of Education, and has worked in five different universities in Nigeria, where he taught English Language and Applied Linguistics as a Senior Lecturer. He later rose to the position of an Associate Professor of Applied Linguistics in Kwara State University Malete, Ilorin, Nigeria. He is currently a retired, contract lecturer in the Department of Linguistics and African Languages, University of Abuja, Nigeria. He has 50 publications, with four books, three of which are: Introduction to Sociolinguistics, Abuja, Mafolayomi Press, 2002; Aspects of 
Applied Linguistics Abuja, Israel Ogunleye Publisher, 2008; Linguistics in Language Education, Abuja, Israel Oguleye publisher, 2009. His previous and current research interest in Ethnography of Communication and Language Documentation.

The author's title is Dr. Olaoye, Associate Professor of Applied Linguistics. He is a member of ten Professional Associations some of which are listed below:

- West African Linguistic Congress (WALC)

- Linguistic Association of Nigeria (LAN)

- Association of Nigerian Languages Teachers (ANLAT)

- Nigerian Institute of Management (NIM)

- Curriculum Organization of Nigeria (CON)

- Nigerian English Studies Association (NESA)

- Reading Association of Nigeria (RAN)

- Standing Conference of Teachers of English Language (SCONTEL)

$\mathrm{He}$ is an awardee of the British Council/Cambridge Summer School Scholarship for Post-Doctoral Language Education Short Course, Homerton College, Cambridge, 1993. He is also a commissioned Language Education Consultant to the National Commission for Colleges of Education (NCCE) and the National Institute for Cultural Orientation (NICO), in Nigeria. 